\title{
THE CHEMICAL CONTENT OF DIFFERENT ENERGY CROPS
}

\section{L.Poiša ${ }^{1}$, A.Adamovičs ${ }^{1}$, L.Antipova ${ }^{2}$, G.Šiaudinis $^{3}$, D.Karčauskien $\dot{e}^{3}$, R.Platače ${ }^{1}$, A.ŽZukauskaitè ${ }^{4}$, S.Malakauskaitè ${ }^{4}, \overline{\text { E. Teirumnieka }}{ }^{5}$}

1- Institute of Agrobiotechnology, Latvia University of Agriculture, Lielā iela 2, Jelgava, Latvia, ph: +(372)63203850, fax: +(372) 63005682, e-mail: lienapoisa@inbox.lv,

Aleksandrs.Adamovics@1lu.lv, rasmins@inbox.lv

2- Mykolayiv State Agrarian University, 9, Paryzka Komuna Str., Mykolayiv, 54010,

Ukraine, ph: +38(0512)346160, fax: +38 (0512) 343146, e-mail: antipova2001@email.ru

3- Vėžaičiai branch of the Lithuanian Research Centre for Agriculture and Forestry, Gargždu

29, Vėžaičiai, LT-96216, Klaipedda district, Lithuania, ph: +(370) 46458233, fax:

+(370)46458233, e-mail: gintaras@vezaiciai.lzi.lt, danuteo@vezaiciai.lzi.lt

4- Klaipėda University, Faculty of Marine Engineering, Bijūnų str. 17, LT-91225 Klaipėda, Lithuania, ph: +(370) 46 398696, e-mail: audrone.zukauskaite@ku.lt, simniona@yahoo.com

5- Rezeknes Augstskola, Faculty of Engineering; Atbrivosanas aleja 76, Rezekne, Latvia

\begin{abstract}
The paper presents the data of gaseous and alkali elements in above-ground biomass of energy crops. The investigations objects were Phalaris arundinacea L., Populus nigra, Artemisia vulgaris, Sylphium perfoliatum, Sida hermaphrodita, Dactylis glomerata, Salix viminalis, Medicago sativia L. The aim of the research: to evaluate the amount of chemical elements in energy crops. Evaluating the energy crops it can be seen, that the most alkaline metals are contained in Sida hermaphrodita, and the least in Sylphium perfoliatum L.
\end{abstract}

Keywords: chemicals elements, energy crops.

\section{Introduction}

In the last few years greater attention has been given world-wide to the importance of biomass for obtaining energy due to the increased demand. Biomass- a biological extracted constituent from the sectors of agriculture and forestry; also from related products, refuse and remains (amongst them- substances originating from plants and animals), as well as from waste from manufacturing and households. It consists of organic substances, which are formed as a result of photosynthesis at present, in contrast to the fossil fuels, which were formed millions of years ago [1]. At present the meadows and pastures of Europe, which up to now guaranteed food stocks for animals, fulfil new functions as environmental stabilizers and as an additional option for renewable energy resources, also forming new directions for research in the cultivation of plants [2].

Energy crops are used widely in various sectors of the economy. They also have a positive effect on the environment, they reduce soil erosion and contamination with chemical substances, they can be grown in soil which cannot be used for food crops [2, 3, 4, 5]. Energy crops have different demand for quality than food and agricultural plants. The alkali metals contented in plants are important factor, as increased amounts facilitate corrosion in heating systems.

The aim of the research: to evaluate the amount of chemical elements in energy crops.

\section{Materials and methods}

Energy crops were tested in the following locations and under the conditions described in Table 1.

The lucerne samples were taken according to the standard requirements GOCT [6]. The chemical analysis of lucerne was carried out at the Mykolayiv State Agrarian University laboratory “Облгосплодородие" according to generally accepted animal husbandry methods. 
Poiša L., Adamovičs A., Antipova L., Šiaudinis G., Karčauskienė D., Platače R., Žukauskaitė A., Malakauskaitė S., Teirumnieka E E. THE CHEMICAL CONTENT OF DIFFERENT ENERGY CROPS

Carbon (C), Oxygen (O), Nitrogen (N), Hydrogen $(\mathrm{H})$, and Sulphur (S) were established at Klaipeda University with the element analyser Vario Macro CHNS-0. Potassium (K), calcium $(\mathrm{Ca})$, sodium $(\mathrm{Na})$ and silicon $(\mathrm{Si})$ concentrations (two replications) in energy crop samples were established with the inductively coupled plasma optical emission spectrometer Perkin Elmer Optima 2100 DV in the Rēzekne Higher Education Institution Chemical laboratory.

Trials' methods in 2010

\begin{tabular}{|c|c|c|c|c|}
\hline \multirow[b]{2}{*}{ Country } & & \multirow[b]{2}{*}{ Ukraine } \\
\hline & & Latvia & Lithuania & \\
\hline Soil type & & $\begin{array}{l}\text { Humi-podzolic gley } \\
\text { soil }\end{array}$ & $\begin{array}{l}\text { Eutri-Endohypostagnic } \\
\text { Albeluvisol, } A B j-n-w \text { - } \\
\text { eu; texture - moraine } \\
\text { loam (clay } 12-14 \% \text { ) }\end{array}$ & $\begin{array}{l}\text { Southern black } \\
\text { earth with little } \\
\text { humus.Remainder- } \\
\text { slightly alkaline, } \\
\text { with a heavy loamy } \\
\text { soil }\end{array}$ \\
\hline \multirow{4}{*}{$\begin{array}{l}\text { Soil } \\
\text { composition }\end{array}$} & $\mathrm{pH}_{\mathrm{KCl}}$ & 5.8 & pH 4.25-4.8 & $6.4-6.7$ \\
\hline & OM, $\%$ & $5.2 \%$ & - & $2.8-3.0 \%$ \\
\hline & $\mathrm{P}_{2} \mathrm{O}_{5}$ & $20 \mathrm{mg} \mathrm{kg}^{-1}$ & $35-120$ (A-L method) & $85 \mathrm{mg} \mathrm{kg}^{-1}$ \\
\hline & $\mathrm{K}_{2} \mathrm{O}$ & $90 \mathrm{mg} \mathrm{kg}^{-1}$ & $\begin{array}{l}144-225(\mathrm{~A}-\mathrm{L} \\
\text { method) }\end{array}$ & $180 \mathrm{mg} \mathrm{kg}^{-1}$ \\
\hline Pre-crops & & Bare fallow & fallow & Bare fallow \\
\hline $\begin{array}{l}\mathrm{N}: \mathrm{P}: \mathrm{K} \\
\text { fertilizers }\end{array}$ & & $\begin{array}{l}\text { N:P:K 5:10:25, } 400 \mathrm{~kg} \\
\text { ha }^{-1}\end{array}$ & 60:60 (P:K) kg ha-1 & P $120 \mathrm{~kg} \mathrm{ha}^{-1}$ \\
\hline Sowing time & & $\begin{array}{l}12^{\text {th }} \text { August in } 2008 \\
29^{\text {th }} \text { April in } 2009\end{array}$ & $14^{\text {th }}$ July in 2009 & $27^{\text {th }}$ March in 2008 \\
\hline Seeding rate & $\mathrm{kg} \mathrm{ha}^{-1}$ & 70 & $\begin{array}{l}15 \mathrm{~kg} \mathrm{ha}^{-1} \text { v.s (viable } \\
\text { seeds) }\end{array}$ & $2-3 \mathrm{~kg} \mathrm{ha}^{-1}$ \\
\hline $\begin{array}{l}\text { Sort or/and } \\
\text { varieties }\end{array}$ & & $\begin{array}{l}\text { Phalaris arundinacea } \\
\text { L. - 'Marathon' }\end{array}$ & $\begin{array}{l}\text { Phalaris arundinacea } \\
\text { L. - 'Chieftain'; } \\
\text { Dactylis glomerata L. - } \\
\text { 'Amba' }\end{array}$ & $\begin{array}{l}\text { Medicago sativa } L \\
\text { 'Sinskia' } \\
\text { (Синская) }\end{array}$ \\
\hline $\begin{array}{l}\mathrm{N} \text { fertilizer } \\
\text { rate }\end{array}$ & $\mathrm{kg} \mathrm{ha}^{-1}$ & N0, N30, N60, N90 & N0, N60, N120 & N15 \\
\hline $\begin{array}{l}\mathrm{N} \text { fertilizer } \\
\text { time }\end{array}$ & & $21^{\text {st }}$ April 2010 & $\begin{array}{l}14^{\text {th }} \text { April (N60 (for } 2^{\text {nd }} \\
\text { and } 3^{\text {rd }} \text { treatments)) and } \\
21^{\text {th }} \text { July (N60 (for } 3^{\text {rd }} \\
\text { treatment)) }\end{array}$ & $1-3^{\text {th }}$ July \\
\hline $\begin{array}{l}\text { Harvesting } \\
\text { time }\end{array}$ & & $6^{\text {th }}$ October & $\begin{array}{l}1^{\text {st }} \text { cutting } 28^{\text {th }} \text { June } \\
\text { (Dactylis glomerata) } \\
\text { and } 7^{\text {th }} \text { July (Phalaris } \\
\text { arundinacea); } \\
2^{\text {nd }} \text { cutting }-30^{\text {th }} \\
\text { September (both } \\
\text { species) }\end{array}$ & $\begin{array}{l}27^{\text {th }} \text { July- } \\
8^{\text {th }} \text { August Or } 8^{\text {th }}- \\
24^{\text {th }} \text { August } \\
\text { Or } 20-30^{\text {th }} \\
\text { September }\end{array}$ \\
\hline Trial plots & & $16 \mathrm{~m}^{2}$ & $14 \mathrm{~m}^{2}$ (for grasses) & $30 \mathrm{~m}^{2}$ \\
\hline Replication & & 3 & 3 & 4 \\
\hline
\end{tabular}

Meteorological conditions in Viḷāni. The air temperature from April to August in the plant growth period was greater than the long-term average, except for September. During April, July and August the precipitation was less than $50 \%$ of the long term average indicators. In 
Poiša L., Adamovičs A., Antipova L., Šiaudinis G., Karčauskienė D., Platače R., Žukauskaitė A., Malakauskaitė S., Teirumnieka E E. THE CHEMICAL CONTENT OF DIFFERENT ENERGY CROPS

June the rainfall amount was $75.7 \mathrm{~mm}$. While the long-term average indicator was 75mm.During May and September the rainfall amount was near the norm.

Meteorological conditions in Vèžaičiai. There was much precipitation in May (indistinctive for spring period) and the rainy period continued until the middle of June. Periodically hot with heavy rainfalls weather continued until the second half of August. For the mentioned period, the average temperature and amount of precipitation were higher than annual. September was a rainy month (excepting the $2^{\text {nd }}$ decade) and the average temperature, slightly lower than the long-term average. During the April-September period, the amount of precipitation was $620.2 \mathrm{~mm}$ (annual average $427.1 \mathrm{~mm}$ ), the sum of average temperatures $2246^{\circ} \mathrm{C}$.

Meteorological conditions in Mykolayiv. The lengthy cool spring hindered the surface biomass development during May. The average air temperature from March to August was $16.8 \mathrm{C}$, the amount of precipitation $267.7 \mathrm{~mm}$.

\section{Results and discussion}

The data of our investigation showed the following chemical content in reed canary grass: nitrogen $(\mathrm{N}) 3.282 \%-4.307 \%$, sulphur $(\mathrm{S})-0.224 \%$ to $0.259 \%$, hydrogen $(\mathrm{H})-6.009 \%$ to $6.761 \%$, carbon (C) $-41.31 \%$ to $45.93 \%$, oxygen $(\mathrm{O})-40.85 \%$ to $47.463 \%$ in reed canarygrass in Latvia (Fig.1). Three elements - C, H and S - are inflammable. As Oxygen (O) and Nitrogen $(\mathrm{N})$ are the internal ballast of the fuel, as these elements do not burn, and do not produce heat and reduce the flammable element percentage content. Oxygen is important as a promoter of combustion. Fuels which have a greater oxygen content fire-wood and peat, catch fire and continue to burn easily. The amount of nitrogen in solid fuels (fire-wood and peat) is small $0.5-2.5 \%$ [7]. N supplementary fertilisers significantly influenced $(\mathrm{p}<0.05)$ the $\mathrm{N}, \mathrm{C}$ and $\mathrm{O}$ content. Only the sowing period $(\mathrm{p}<0.05)$ influenced the nitrogen, carbon and oxygen content in plants.

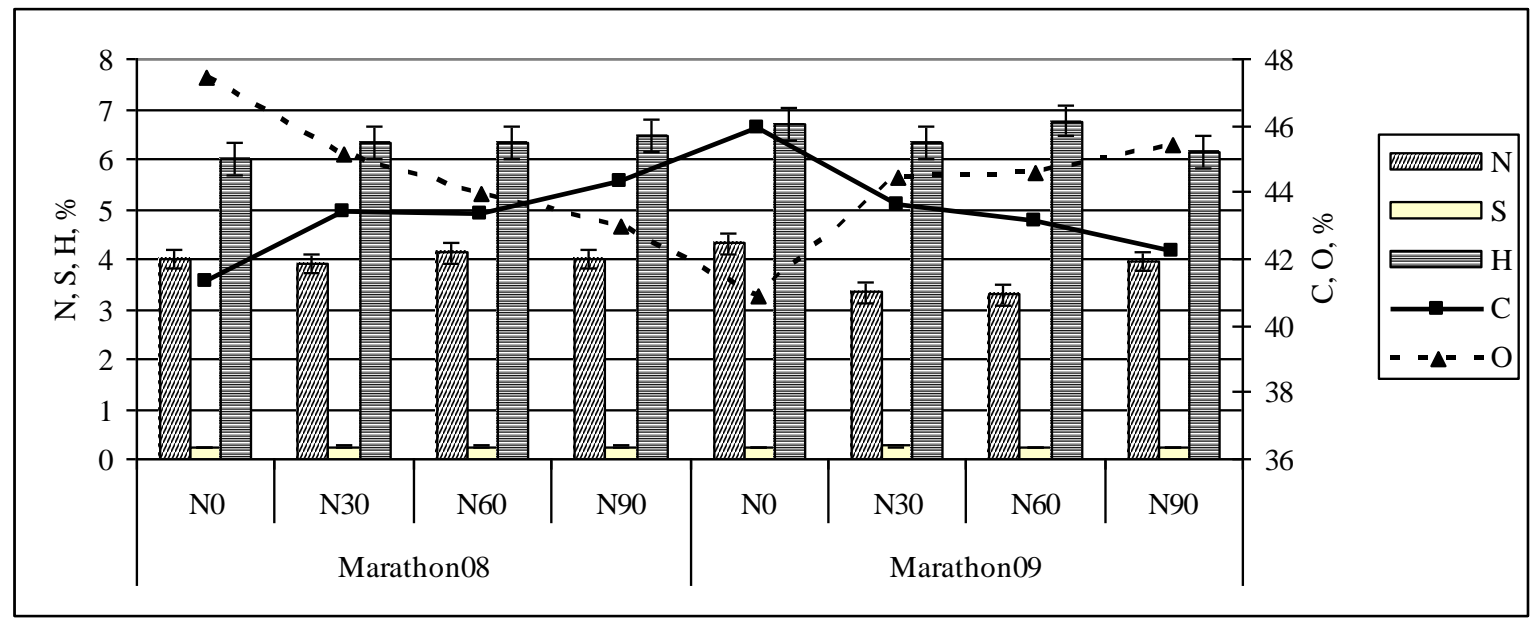

Fig. 1. The Carbon (C), Oxygen (O), Nitrogen (N), Hydrogen (H), and Sulphur (S) contents for the reed canary grass variety 'Marathon' second year crop in Latvia 2010, \%

The sulphur content in coal is from $1 \%$ to $4 \%$. In petroleum sulphur content is from $0.3 \%$ to $3 \%$ [1]. In our research the sulphur content for reed canary grass variety 'Marathon' is smaller than the amount found in oil, which confirms, that the biomass plants do not endanger the surrounding environment.

The ash content in lucerne ranged from 7.9 to $13.9 \%$, but in woodpulp from 12 to $28 \%$, dependant on the plant segment (Fig.2). The chemical element content in lucerne is dependant on the plant segment $(\mathrm{p}<0.05)$. 
Poiša L., Adamovičs A., Antipova L., Šiaudinis G., Karčauskienė D., Platače R., Žukauskaitė A., Malakauskaitė S., Teirumnieka E. THE CHEMICAL CONTENT OF DIFFERENT ENERGY CROPS

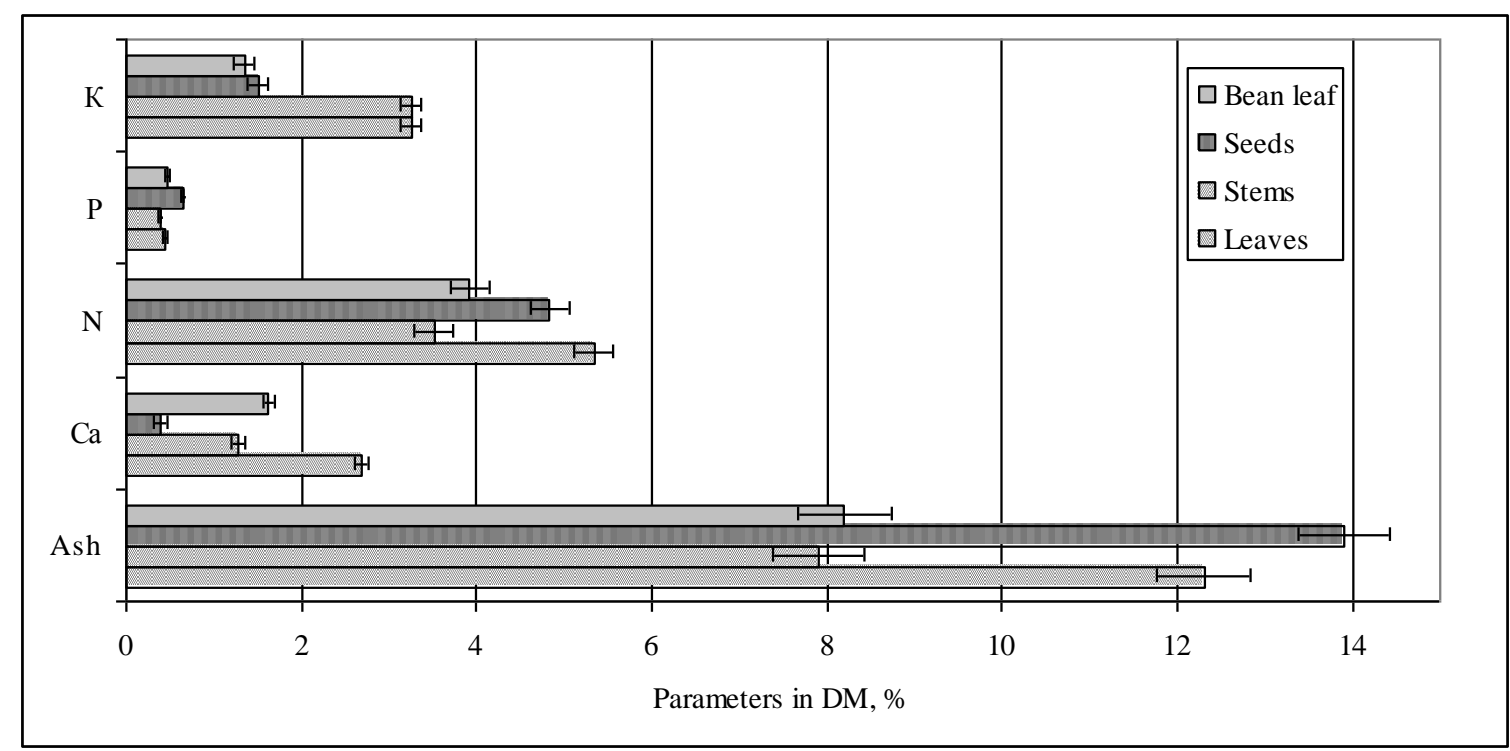

Fig.2. The ash and chemical elements in Medicago sativa L. dry matter, \%

The crop yield in the southern Ukraine was $4.7-5.0 \mathrm{t} \mathrm{ha}^{-1}$ and yield and chemicals elements was dependant on the amount of precipitation in the plant growth period [8].

Comparing five energy crops, it is obvious, that the most alkali metals are contained in Sida hermaphrodita; meanwhile in Sylphium perfoliatum - the least. (Fig.3). N fertilizer rates were significantly $(\mathrm{p}<0.05)$ the chemicals elements in energy crops.

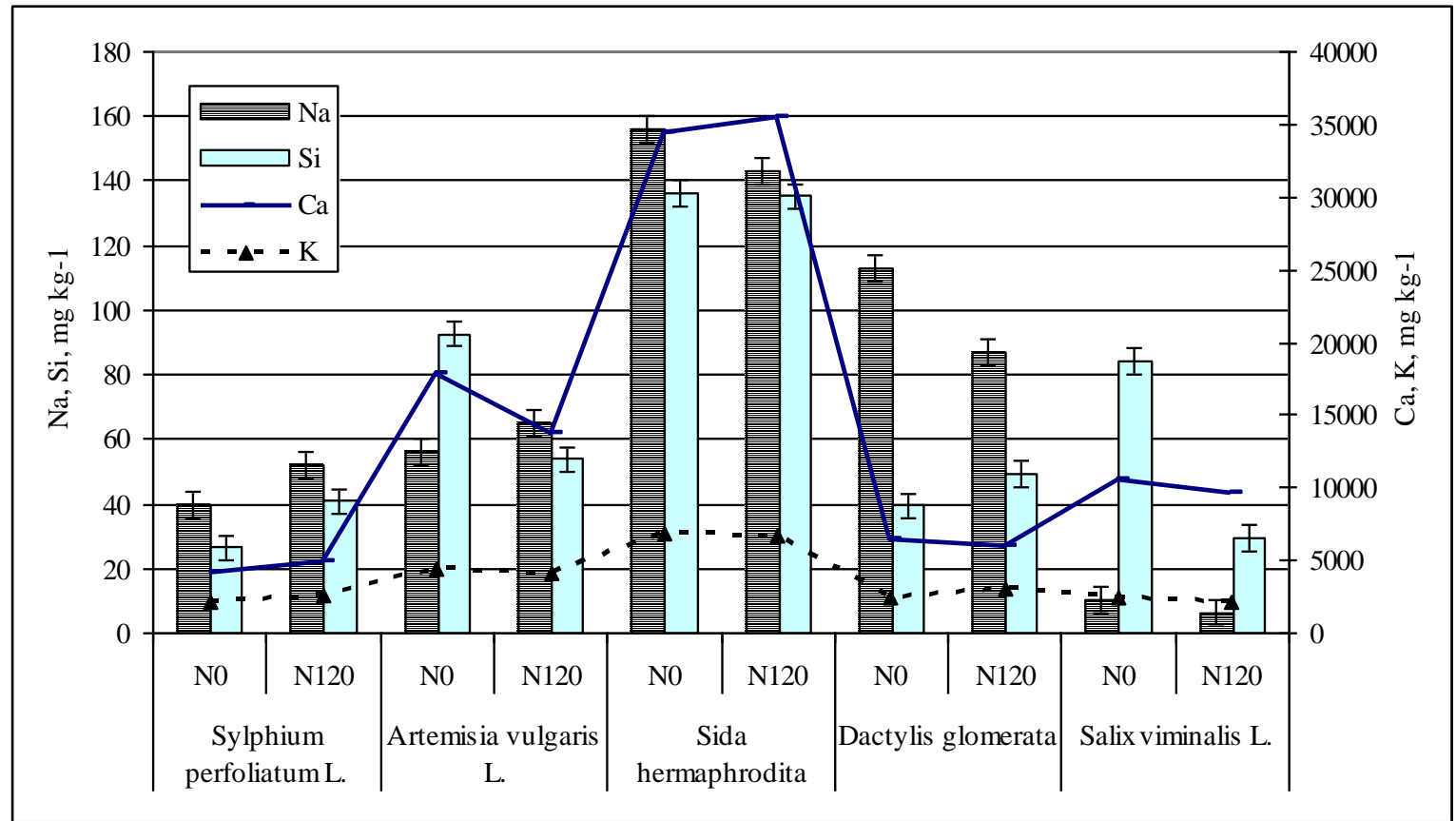

Fig.3. The chemical content of different energy crop plants in Lithuania

Calcium $(\mathrm{Ca})$, sodium $(\mathrm{Na})$ and silicon showed that it in Latvia higher than Lithuania in reed canary grass (Fig.4). That shows not only the influence of climatic conditions, but also influence of the soil $\mathrm{pH}$ content, and the plant variety. 
Poiša L., Adamovičs A., Antipova L., Šiaudinis G., Karčauskienė D., Platače R., Žukauskaitė A., Malakauskaitė S., Teirumnieka E. THE CHEMICAL CONTENT OF DIFFERENT ENERGY CROPS

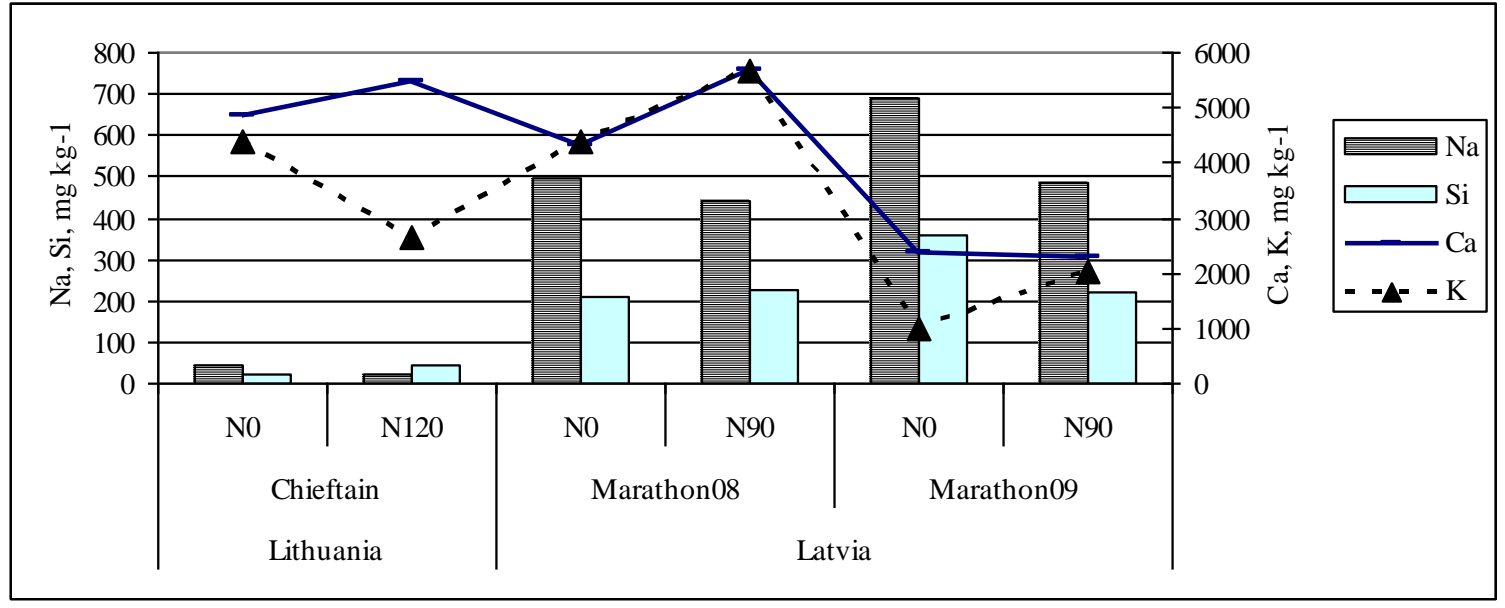

Fig. 4. The chemical content of reed canarygrass depends on the agro-climatic conditions and the $\mathbf{N}$ fertilizer rate

Comparing the reed canary grass grown in Latvia according to the chemical content, it can be seen that it contains more alkali metals than other energy crop plants, which is not desirable when used for biofuel production (Fig. 3, Fig.4). Straw, cereals, grass and grain can contain comparatively large amount of $\mathrm{Cl}, \mathrm{S}$ and alkali metals, which have a significant relationship for corrosions and sediment formation [9]. Silicon connections strengthen the plant stems, therefore averting plant collapse [10]. An increased dose of fertilizer, rainwater and other contaminants from groundwater pollution caused by nitrates significantly degrades the soil properties, reducing its fertility $[11,12]$.

\section{Conclusions}

The reed canary grass grown in Latvia contains a larger amount of alkali metals, than the energy crop plants grown in Lithuania, therefore the conditions of sowing must be carefully assessed. The ash content in lucerne is from $7.9 \%$ - 13.9\%, but in woodpulp from $12 \%-28 \%$ dependant on the plant segment. The chemical content of lucerne is dependant on the plant segment $(\mathrm{p}<0.05)$. In the Ukraine for the growing lucerne the $\mathrm{N}$ content was $3.5 \%-5.34 \%$. The $\mathrm{N}$ content in Latvia for the growing reed canary grass ranges from $3.282 \%$ to $4.307 \%$, which is greater than what was found in other research; but the $\mathrm{S}$ is in a range of $0.224 \%$ to $0.259 \%$, which is less than in fossil fuel. The sowing period $t(p<0.05)$ influenced the nitrogen, carbon and oxygen content in the plants. Evaluating the energy crop plants grown in Lithuania, it can be seen, that the most alkaline metals are in Sida hermaphrodita, but the least in Sylphium perfoliatum L.

\section{Acknowledgment}

The study was supported by ESF Project 2009/0225/1DP/1.1.1.2.0/09/APIA/VIAA/129.

I (L. Poiša) would like to thank the Vitols Fund and the LAB-AN (Latvian Agronomic Society - Foreign Department) for granting me a bursary.

The authors also would like to thank the Agricultural Science Centre of Latgale for reed canarygrass installation assistance; the Rēzekne Higher Education Institution of Chemistry Laboratory assistants S. Augule for the help with the metal analysis. 
Poiša L., Adamovičs A., Antipova L., Šiaudinis G., Karčauskienė D., Platače R., Žukauskaitė A., Malakauskaitė S., Teirumnieka E E. THE CHEMICAL CONTENT OF DIFFERENT ENERGY CROPS

\section{References}

1. Vides zinātne. Kḷaviņš, M., Nikodemus, O., Segliņš, V. u.c. Rīga: Latvijas Universitāte, 2008, 599 lpp. (in Latvian).

2. Кулаковская, Т., Кургак, В., Адамович, А. Основные направления исследований и экологические аспекты развития лугопастбищного хозяйства в Европе. Корми і кормовиробництво. Міжвідомчий тематичний науковий збірник. Випуск 67, Вінниця, 2010,135-142 с. (in Russian).

3. Enerǵētisko augu audzēšana un izmantošana. Adamovičs A., Agapovs J., Aršanica A. u. c. Rīga: Valsts SIA ,Vides projekti”, 2007, 190 lpp. (in Latvian).

4. Sanderson, M.A., Adler, P.R. Perennial Forages as Second Generation Bioenergy Crops. International Journal of Molecular Sciences. Vol. 9. No. 5, 2008, p. 768-788.

5. Wrobel, C., Coulman, B. E., Smith, D. L. The potential use of reedcanarygrass (Phalaris arundinacea L.) as a biofuel crop. Acta Agriculturae Scandinavica, Vol. 59, 2009, p. 1-18.

6. ГОСТ 13.586.3-83. Правила приемки и методы отбора проб. Срок действия с 01.07.84. (in Russian).

7. Cars, A. Energoresursi. Rīga: SIA Baltic Communication Partners. 2008, 102 lpp. (in Latvian).

8. Антипова, Л. К. Виробництво насіння люцерни в Степу України : моногр. / Л. К. Антипова. Миколаїв: МДАУ, 2009, 227 с. (in Ukrainian).

9. Biedermann, F., Obernberger, I. Ash-related problems during biomass combustion and possibilities for a sustainable ash utilisation. 2005, [tiešsaiste] [skatīts 2010. g. 21. janv.]. Pieejams: www.biosbioenergy.at/uploads/media/Paper-Biedermann-AshRelated-2005-10-11.pgf.

10. Zelčāns, G., Lukevics, E. Silīcijs dzīvajā dabā. Rīga: Zinātne, 1976, 75 lpp. (in Latvian).

11. Bramley, R. G. V. Cadmium in New Zealand agriculture. New Zealand Journal of Agricultural Research. Vol. 33, No. 4, 1990, p. 505-519.

12. Минеев В. Г. Агрохимия и биосфера. 1984. 245 с. (in Russian).

\section{Kopsavilkums}

Pētījuma mērķis: novērtēt ķīmisko sastāvu dažādiem enerğētiskajiem augiem. Pētījuma objekti: Phalaris arundinacea L., Populus fascigiata, Artemisia vulgaris, Sylphium perfoliatum, Sida hermaphrodita, Dactylis glomerata, Salix viminalis, Medicago sativa L. Mūsu pētījumā iegūtais N saturs miežabrālim svārstās robežās no 3.282\% lìdz 4.307\%, S- 0.224\% - 0.259\%, H - 6.009-6.761\%, C-41.31\% - 45.93\%, O - 40.85\% 47.463\%. Sēra daudzums miežabrāḷa šķirnei 'Marathon' ir mazāks par naftā esošo sēra daudzumu. Pelnu saturs lucernā ir no 7.9 - 13.9\%, bet kokšķiedras - 12 - 28\% atkarībā no auga dal̦as. Ķ̄̄misko elementu daudzums lucernā ir atkarīgs no auga daļas (p<0.05). Visvairāk sārmu metālu satur Sida hermaphrodita, bet vismazāk Sylphium perfoliatum L. Sārmu metālu daudzums augos ir svarīgs faktors, jo to klātbūtne veicina korozijas veidošanos apkures sistēmās. 